\title{
EVALUATION OF EFFECTIVENESS OF MEDICAL AND ORGANIZATIONAL CARIES PREVENTION MEASURES DESIGNED FOR WORKING POPULATION
}

\author{
Kopetsky IS 1 , Virgilyev PS ${ }^{\bowtie}$, Pobozhieva LV', Stupakov IN² \\ Faculty of Dentistry, Pirogov Russian National Research Medical University, Moscow
}

2 Bakulev National Medical Research Center of Cardiovascular Surgery

Today, a dentist can make use of any of the multitude of methods to forecast treatment effectiveness, restoration lifetime, new caries lesions development risks. However, at the national level we see no studies dedicated to evaluation of clinical effectiveness of the majority of those methods. Having analyzed the available literature, we selected CAMBRA caries development risk assessment method and made it a goal of this study to evaluate its effectiveness while also seeking to develop the most effective treatment plan. We examined 126 young adults without concomitant somatic pathologies and divided them into treatment and control groups; treatment group was then further subdivided into 3 groups depending on the risk of caries development. All patients had their teeth and tissues of the oral cavity treated following the developed and the classic plans, accordingly. After 12 months, follow-up examinations of the treatment group revealed new caries lesions in 34 (43.5\%) patients, while 40 (51.3\%) were diagnosed with periodontal diseases. In the control group, we found new cavities on the teeth of 25 (52.1\%) patients and periodontal pathologies in 28 (58.3\%) study participants. This research shows that CAMBRA and the developed treatment plan can decrease the rate of caries development in young adults.

Keywords: caries risk assessment, CRA, CAMBRA, treatment prognosis, OHI-S, CPE, CPITN, filling material

$\triangle$ Correspondence should be addressed: Pavel S. Virgilyev

Ostrovityanova 1, build. 7, Moscow, 117997; Vivisector25@yandex.ru

Received: 04.07.2018 Accepted: 03.09.2018

DOI: $10.24075 / \mathrm{brsmu} .2018 .070$

\section{ОЦЕНКА ЭФФЕКТИВНОСТИ МЕДИКО-ОРГАНИЗАЦИОННЫХ МЕРОПРИЯТИЙ ПО ПРОФИЛАКТИКЕ КАРИОЗНЫХ ПОРАЖЕНИЙ У ЛИЦ ТРУДОСПОСОБНОГО ВОЗРАСТА}

И. С. Копецкий ${ }^{1}$, П. С. Виргильев ${ }^{1 凶}$, Л. В. Побожьева ${ }^{1}$, И. Н. Ступаков ${ }^{2}$

Стоматологический факультет, Российский национальный исследовательский медицинский университет имени Н. И. Пирогова, Москва.

${ }^{2}$ Национальный медицинский исследовательский центр сердечно-сосудистой хирургии имени А. Н. Бакулева

\begin{abstract}
В настоящее время в стоматологии существует множество методов, позволяющих спрогнозировать эффективность лечения, срок службы реставрации и риск появления нового кариозного поражения зубов, но в отечественной литературе нет результатов оценки клинической эффективности большинства методик. На основании анализа литературных данных была выбрана методология CAMBRA для определения риска развития кариеса. Целью исследования было определить эффективность данной методики, а также составить наиболее эффективный план лечения. Были обследованы 126 пациентов молодого возраста без сопутствующей соматической патологии, их разделили на основную и контрольную группы, основную группу разделили на 3 подгруппы, в зависимости от риска развития кариеса. Всем пациентам провели санацию полости рта по разработанной и классической методике соответственно. Через 12 месяцев на повторном осмотре в основной группе у $34(43,5 \%)$ пациентов появился новый кариозный процесс. У 40 (51,3\%) человек были выявлены заболевания пародонта. В контрольной группе у 25 (52,1\%) пациентов появились кариозные полости, 28 (58,3\%) имели патологию тканей пародонта. Исследование показывает, что CAMBRA и разработанная методика позволяют снизить прирост кариеса у пациентов молодого возраста.
\end{abstract}

Ключевые слова: риск развития кариеса, CRA, CAMBRA, прогноз лечения, планирование лечения, ИГР-У, КПУ, CPITN, пломбировочный материал

$\triangle$ Для корреспонденции: Павел Сергеевич Виргильев ул. Островитянова, д. 1, стр. 7, г. Москва, 117997; Vivisector25@yandex.ru Статья получена: 04.07.2018 Статья принята к печати: 03.09.2018 DOI: $10.24075 /$ vrgmu.2018.070

The CFE ("caries-filling-extraction") index peculiar to the residents of Russia aged 35-44 years is 14.4, which is a high rate of incidence of caries. Moreover, despite the ongoing prevention programs, it tends to grow [1]. At the initial oral examination of patients with multiple caries lesions, CFE does not describe the real situation: patients that score the same values can have completely different clinical pictures. It cannot be reliably argued that after treatment the patient will not have recurrent or secondary caries [2].
According to some authors, an objective assessment of the oral cavity's condition requires determining the CFE index, oral hygiene index, severity of dental caries, analyzing the orthopantomogram (OPG), thorough instrument-aided examination of proximal surfaces for hidden cavities, as well assessment of the patient's periodontal status [3, 4].

Today, there is a multitude of methods to forecast the risk of the new caries development: software solutions that calculate the risk of caries development using the patient data 
(Cariogram, Risk Profile); statistical methods (caries intensity index, CII); methods implying assessment of the saliva's physicochemical properties, i.e. its viscosity, $\mathrm{pH}$, secretion rate (Salivary multi test meter) and buffer capacity (Saliva check-buffer); tests to approximate the number of bacteria that cause caries, e.g. Streptococcus mutans (Saliva checkmutans, Clinpro cario L-Pop (3M); Dentocult SM) or Lactobacili (Dentocult LB); tests to determine the dental plaque's $\mathrm{pH}$, maturity and volume (Plaque indicator kit) [5, 6]; a questionnaire (caries risk assessment, CRA) [7].

In addition to the questionnaire, some dentists use Clinpro cario L-Pop (3M), a rapid test deriving the number of cariogenic bacteria from the amount of sucrose processed by them, and Saliva check-buffer and Saliva check-mutans, diagnostic test kits (incl. special test strips and reagents) telling the physicochemical properties of saliva within 15-20 minutes. Plaque indicator kit occupies a place of its own: this is a set of 5 minute tests that enable learning the $\mathrm{pH}$ of dental plaque and its maturity, thus allowing the dentist to show the patient the "problematic areas" and assess the level of oral hygiene [5]

Some of these tests (CRA, CariScreen, OPG, clinical examination) are part of the CAMBRA (Caries Management By Risk Assessment) method developed by the California Dental Association in 2011. The method is widely used in Western countries (USA, UK, France, the Netherlands), but it is not popular in Russia [8-10].

This study aimed to compare the available caries lesions and caries risk assessment methods, determine which of them is the most effective, and develop the rational treatment plan that factors in the specific levels of risk.

\section{METHODS}

The study involved 126 young adults. The inclusion criteria were: 1) men and women 18-44 years old; 2) presence of carious cavities; 3) no registered concomitant pathologies. The exclusion criteria were: 1) ages other than 18 to 44; 2) no carious cavities; 3) presence of concomitant somatic pathologies. The design of this research was approved by the ethical committee of N. I. Pirogov Russian National Research Medical University (Minutes \#15 of 2016.11.10). All participants filled the CRA questionnaire and signed the informed voluntary consent form; they were divided into two groups: treatment $(n=78)$ and control $(n=48)$. Each patient had his/her OHI-S, CII indices determined, medical history collected, oral cavity and OPG examined, treatment plan compiled. At the treatment stage, all patients were trained proper oral hygiene routines, had their teeth cleaned by a professional dental hygienist and caries lesions (incl. complications thereof) treated. The followup examinations were conducted 6 and 12 months after treatment.

To process and analyze the data obtained, we used Microsoft Excel 2010, vertically compared relative values by independent sets and observation series, applied ANOVA to quantity.

For the purposes of this study, we chose the CAMBRA method and adjusted it to our clinical conditions (see below). This method determines the risk of caries development (primary and secondary) through clinical instrument-aided examination of the oral cavity, CariScreen dental plaque analysis, OPG examination, patient interview (to fill the medical history) and CRA questionnaire that the patient fills before the first visit to the dentist.

The CRA questionnaire included questions about diet, individual oral hygiene, somatic pathologies (cardiovascular diseases, endocrine system disorders, general metabolic and calcium and phosphorus metabolism disorders), bad habits, previous visits to the dentist, as well as the consent form confirming the patient's willingness to participate in the study. This questionnaire shows patients the plethora of different factors that affect the health of their oral cavity and should encourage them to proceed with the treatment.

Instead of the CariScreen system, which is not popular in our country, we used the OHI-S index by J. C. Green, J. R. Vermillion as modified by P. A. Leus. The index allows learning the amount of plaque and scale accumulated in the patietn's teeth. The $\mathrm{OH}-\mathrm{S}$ procedure implies examining buccal surfaces of teeth $16,11,26,31$ and lingual surfaces of teeth 36 and 46. Dye (erythrosine, fuchsin) applied to those surfaces improves visualization of the plaque. Both soft and hard scale deposits are taken into account: the former on the tooth's surface, the latter supra- and subgingival. The index value is the the sum of codes describing each tooth divided by the number of teeth examined.

$\mathrm{CFI}$ index is the sum total of the number of carious teeth, number of filled teeth and number of extracted teeth. A value greater than 10 signals of intensive development of caries.

To determine if the patients had their periodontal tissues affected by any pathology, we calculated CPITN, Community Periodontal Index of Treatment Needs. The process implies using a special CPITN clinical periodontal probe to examine gingival sulcus, gum tissues for bleeding, as well as measuring sub- and supragingival plaque deposits and gingival pockets, if any. The treatment plan depends on the value of this index.

Apart from CPITN, the state of periodontal tissues can be determined with the help of OPG, which also helps discover hidden carious lesions. Examining the OPG taken with a system like Vatech Pax-i3D (Samsung; Korea) or Planmeca ProMax 3D (Planmeca; Finland), a dentist can find manifestations of periodontal diseases and caries lesions on proximal surfaces of the teeth, which are hard to diagnose in the context of the regular examination routine.

The survey and the methods described above allowed dividing the patients into groups by the caries risk factor, from very low to extremely high.

To determine the severity of caries, we used the Nikiforuk classification as modified by A.I. Nikolaev and L.M. Tsepov; this classification puts patients into three groups [2]:

- initial caries; clinical manifestations: signs of decay on fissures and proximal surfaces of molars (CFE index value below 8);

- moderate caries; clinical manifestations: lesions on fissures and proximal surfaces of molars and second premolars, single lesions on proximal surfaces of anterior teeth (CFE index value 9 to 12 );

- severe caries; clinical manifestations: lesions on fissures

Table 1. Treatment group patients divided into subgroups by risk factor and caries severity

\begin{tabular}{|l|l|c|c|}
\hline Risk group Risk factor & Risk acc. to CRA & OHI-S value & Periodontal pathology \\
\hline Subgroup I (low risk) & Low to moderate & $0-1.2$ & No \\
\hline Subgroup II (moderate risk) & Moderate to high & $1.3-3.0$ & Initial \\
\hline Subgroup III (high risk) & High to very high & Over 3.1 & Gingivitis \\
\hline
\end{tabular}


and proximal surfaces of molars and premolars, lesions on proximal surfaces of anterior teeth, cervical caries (CFE index value 9 to 12).

CPITN helped assess the state of the patient's periodontal tissues.

Thus, applying the CAMBRA method and factoring in the examination data, we divided treatment group participants into 3 subgroups depending on the risk factor and caries severity (Table 1).

Different risk groups had different treatment plans. Patients in subgroup I had only initial caries lesions and exhibited a high $\mathrm{OHI}-\mathrm{S}$ value; after professional teeth cleaning (soft plaque removal with air abrasion, hard plaque removal with a US scaler, teeth polishing), caries lesions in their teeth were removed mechanically, then prepared for adhesive restoration and restored with a nanohybrid light-cured composite resin following the ethanol protocol (prepared cavity treated with $2 \%$ chlorhexidine ethanol solution) [11], no liner.

$\mathrm{OHI}-\mathrm{S}$ values peculiar to subgroup ॥ patients were satisfactory; caries lesions discovered on their teeth were moderate. On the CPITN scale they scored 1 to 2 points, therefore, in addition to professional teeth cleaning, these patients were taught rational oral care routines, and a week later they had the oral hygiene status checked again and brushed teeth under supervision. Caries lesions found in these patients were removed mechanically, teeth prepared for adhesive restoration and restored with a nanohybrid light-cured composite resin following the ethanol protocol; for the liner, we chose a dual cure glass ionomer cement (GIC), thus applying the "closed sandwich" technique. GIC releases fluoride ions, which makes liners made of this material bacteriostatic, i.e. capable of preventing secondary caries [2, 12].

Oral hygiene status of subgroup III patients was unsatisfactory, most of them had over 6 caries lesions on their teeth. The CPITN value was above 2, so we used Vector system to treat periodontal pockets in 4 patients with mild periodontitis. Vector (Durr dental; Германия) system was designed to enable administration of drugs in periodontal pockets, perform scaling and root planing. Other patients had their teeth cleaned by a professional dental hygienist. Carious lesions found on the proximal surfaces were removed mechanically, then the teeth were prepared for adhesive restoration, cavities filled with a nanohybrid composite resin over a GIC liner ("open sandwich" technique) [2, 13]. For decay found on occlusal surfaces we used a tri-cure GIC. Glass ionomer cements possess the "battery" power: they adsorb fluoride ions from special

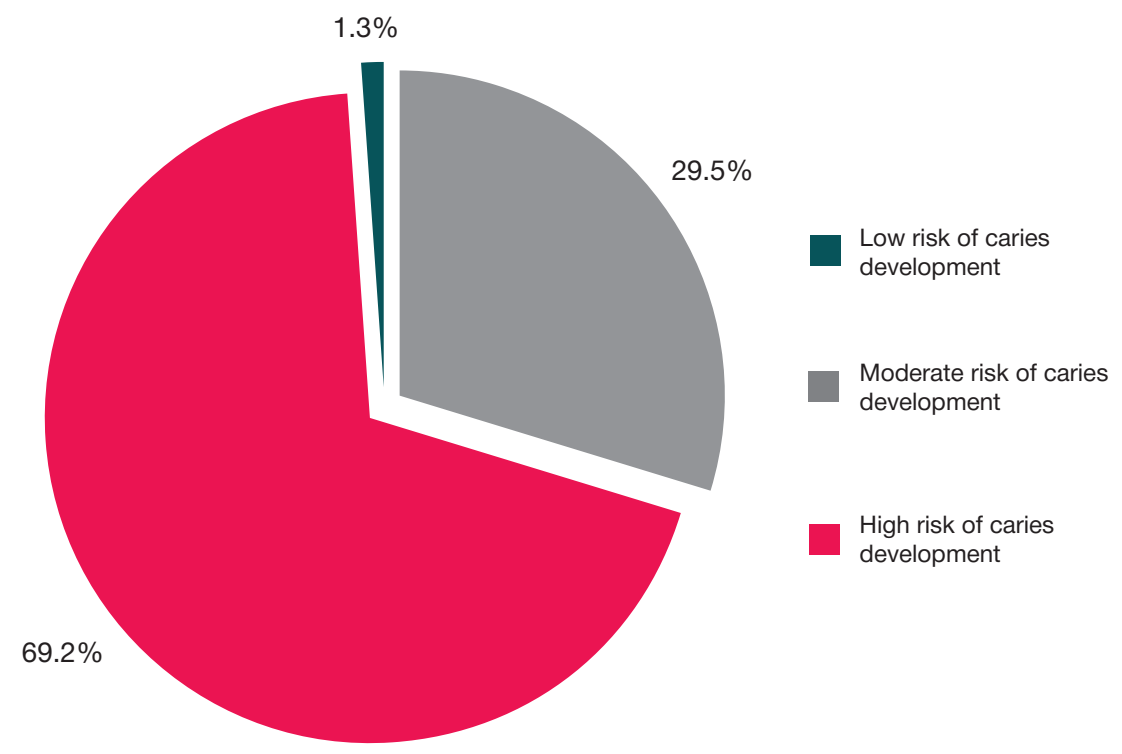

Fig. 1. Distribution of patients into risk groups

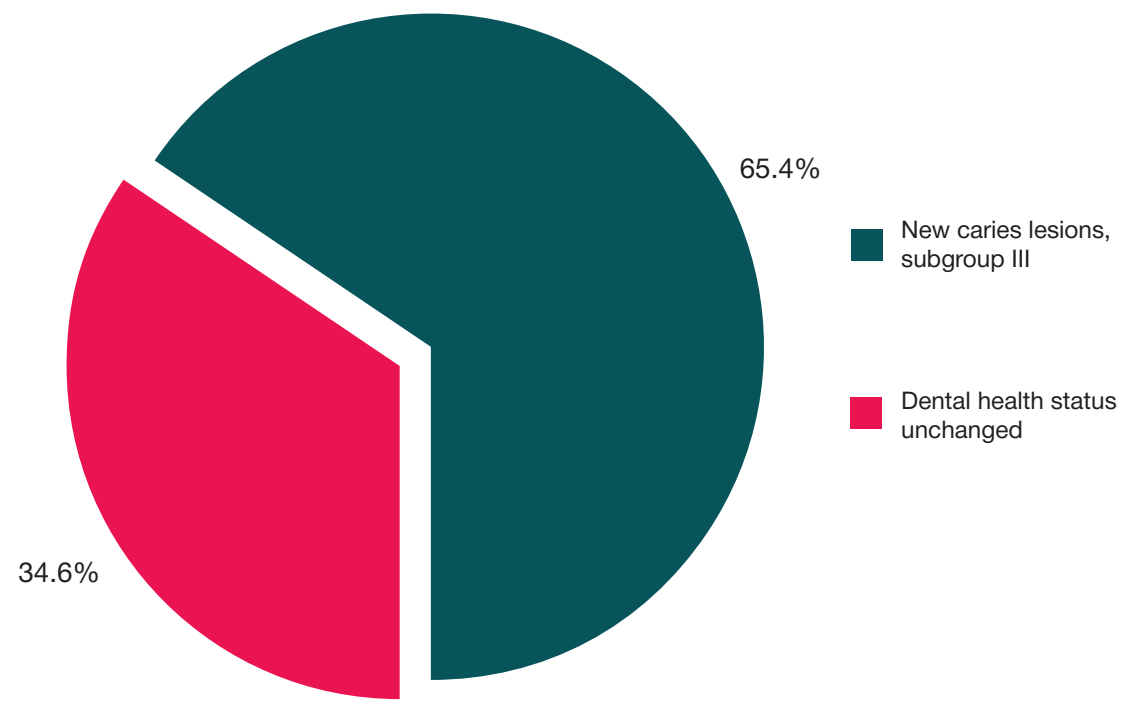

Fig. 2. Dental health status change, 6 months follow-up, treatment group 


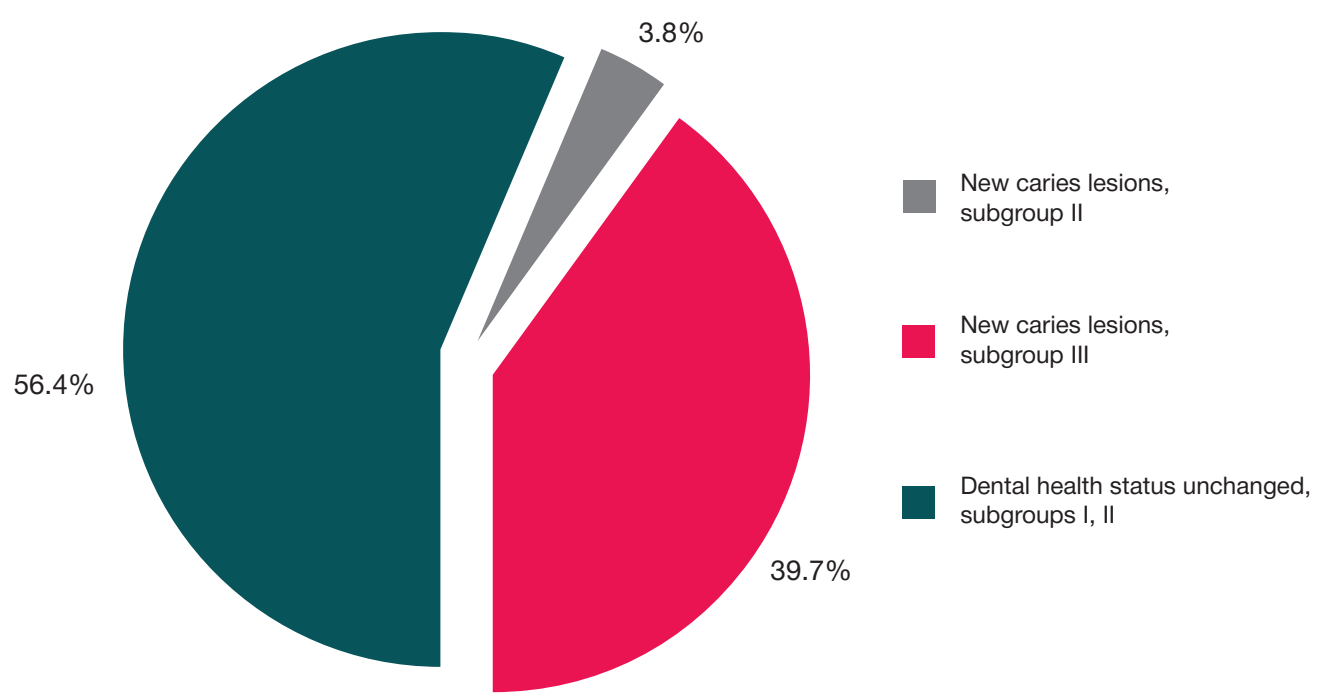

Fig. 3. Dental health status change, 12 months follow-up, treatment group

toothpastes and then release them when the $\mathrm{pH}$ level in the oral cavity goes down [14].

Control group patients underwent professional teeth cleaning, periodontal treatment, had their caries lesions removed and affected teeth prepared for adhesive restoration, then restored with a nanohybrid light-cured composite resin over a liner (standard technique, as decided upon by the attending dentist).

At the follow-up visits, 6 and 12 months after the initial treatment, new caries lesions in all participants (both control and treatment groups) were treated following the same routines as were applied during the first stage of the study.

\section{RESULTS}

Initial examination revealed that in the treatment group:

-23 patients ran a moderate risk of new caries development (subgroup II);

- 54 patients ran a high risk of new caries development (subgroup III);

According to the CPITN:

-77 patients had pathological changes in periodontal tissues (gingivitis in $93.5 \%$ of patients, mild periodontitis in $3.9 \%)$

-1 patient had healthy periodontal tissues (Fig. 1).

Initial examination of the 48 patients of the control group revealed that:

- their mean OHI-S value was 2.3 (satisfactory oral hygiene level);

- mean CFE index was 9.7 (moderate caries development intensity);

- 43 of them had pathological changes in periodontal tissues (gingivitis in $88.4 \%$ of patients, mild periodontitis in $11.6 \%)$;

At the 6 months follow-up examinations (Fig. 2), we discovered new caries lesions on intact or treated teeth of $27(34.6 \%)$ patients, learned that $36(46.1 \%)$ patients did not follow the oral care recommendations and registered no visible change in dental health status of 51 (65.4\%) patient. Only the patients of subgroup III (high risk) exhibited new caries lesions. We registered no inflammatory periodontal diseases in 42 (53.8\%) patients from subgroups I and II who observed the rational oral hygiene recommendations. Chronic catarrhal gingivitis and mild periodontitis were diagnosed in $46.1 \%$ of the patients.

At the follow-up examination, 20 (41.7\%) control group patients had new carious lesions and 27 (56.3\%) - periodontal tissue pathologies.

After 12 months (Fig. 3), despite all measures taken, 31 (39.7\%) patient from subgroup III and 3 (3.8\%) patients from subgroup II had the new caries lesions developing. Only 44 (56.4\%) participants had no visible changes to their dental health status; these patients belonged to all caries risk subgroups. In 38 (48.7\%) patients from subgroups I and II that followed the rational oral hygiene recommendations we found no inflammatory periodontal diseases. Forty (51.3\%) patients were diagnosed with chronic catarrhal gingivitis and mild periodontitis.

In the control group 25 (52.1\%) patients had new caries lesions and 28 (58.3\%) - periodontal tissue pathologies.

\section{CONCLUSIONS}

We discovered that 6 month after the first examination and treatment, 27 (34.6\%) of subgroups II and III patients had new caries lesions; 12 months after, the figure increased to $34(43.5 \%)$. In the control group, the new lesions were found in $20(41.7 \%)$ patients after 6 months and in 25 (52.1\%) patients after 12 months. The results allow a conclusion that the CAMBRA method combined with calculating the probability of caries development allows predicting remote treatment results, be it planned or performed.

Follow-up periods differ for different patients and depend on the specifics of the groups the patients belong to. Subgroup I patients can have the follow-up examination 12 months after treatment, while those belonging to subgroup II should visit the dentist 6 months earlier. Subgroup III patients should come to the dentist's office more often: higher caries risk requires dental health examinations every 3 months.

The choice of filling and restoration techniques also depends on the risk group the patient belongs to. Classic technique is good for those running low caries development risk, while moderate risk group would benefit from adding GIC as a liner, and patients whose caries risk level is high should have their teeth filled and restored following the "open sandwich" technique or with application of GIC. 


\section{References}

1. Kuzmina JeM. Stomatologicheskaja zabolevaemost' naselenija Rossii. MGMSU. M., 2009; 225 s.

2. Nikolaev Al, Cepov LM. Prakticheskaja terapevticheskaja stomatologija. M.: MEDpress-inform, 2014; 928 s.

3. Dmitrieva LA, Maksimovskij JuM, redaktory. Terapevticheskaja stomatologija: nacional'noe rukovodstvo. M.: GJeOTAR-Media, 2015; 888 s.

4. Zharkova OA. Sovremennye podhody k diagnostike faktorov riska vozniknovenija kariesa. Vestnik VGMU. 2010; (3): 6.

5. Skatova EA, Makeeva MK, Shakarjanc AA. Prakticheskie aspekty opredelenija riska razvitija kariesa. Problemy stomatologii. 2010; (3): 13-19.

6. Kopeckij IS, Pobozh'eva LV. Rol' bioplenki $v$ patogeneze vospalitel'nyh zabolevanij polosti rta i sposoby ee ustranenija. Lechebnoe delo. 2012; (2): 9-13.

7. Smirnova MA. Zakonomernosti razvitija, principy kompleksnogo lechenija i profilaktiki kariesa kontaktnyh poverhnostej zubov [dissertacija]. Tver', 2009.

8. Jenson D, Budenz AW, Featherstone JDB, Ramos-Gomez F, Spolsky VW, Young DA. Clinical protocols for caries management by risk assessment. J Calif Dent Assoc. 2007; 35 (10): 714-23.

\section{Литература}

1. Кузьмина Э. М. Стоматологическая заболеваемость населения России. МГМСУ. М., 2009; 225 с.

2. Николаев А. И., Цепов Л. М. Практическая терапевтическая стоматология. М.: МЕДпресс-информ, 2014; 928 с.

3. Дмитриева Л. А., Максимовский Ю. М., редакторы. Терапевтическая стоматология: национальное руководство. М.: ГЭОТАР-Медиа, 2015; 888 с.

4. Жаркова О. А. Современные подходы к диагностике факторов риска возникновения кариеса. Вестник ВГМУ. 2010; (3): 6.

5. Скатова Е. А., Макеева М. К., Шакарьянц А. А. Практические аспекты определения риска развития кариеса. Проблемы стоматологии. 2010; (3): 13-19.

6. Копецкий И. С., Побожьева Л. В. Роль биопленки в патогенезе воспалительных заболеваний полости рта и способы ее устранения. Лечебное дело. 2012; (2): 9-13.

7. Смирнова М. А. Закономерности развития, принципь комплексного лечения и профилактики кариеса контактных поверхностей зубов [диссертация]. Тверь, 2009.

8. Jenson D, Budenz AW, Featherstone JDB, Ramos-Gomez F, Spolsky VW, Young DA. Clinical protocols for caries management by risk assessment. J Calif Dent Assoc. 2007; 35 (10): 714-23.
9. Ramos-Gomez F, Yasmi CO, Man WN, Crall JJ, Featherstone JDB. Pediatric Dental Care: Prevention and management protocols based on caries risk assessment. J Calif Dent Assoc. 2010; 38 (10): 746-61.

10. Uma Maheswari S, Raja Jacob, Arvind Kumar I, Gnana Seelan R. Caries management by risk assessment: A review on current strategies for caries prevention and management. I Pharm Bioallied Sci. 2015 Aug; 7 (Suppl 2): 320-4.

11. Lorenzo Breschi, Annalisa Mazzoni, Fernando Nato, Marcela Carrilho, Erika Visintini, Leo Tjäderhane, Alessandra Ruggeri, Franklin R. Tay, Elettra De Stefano Dorigo, David H. Pashley. Chlorhexidine stabilizes the adhesive interface: A 2-year in vitro study. Dental Materials. 2010; 26 (4): 320-5.

12. Pojurovskaja IJa. Stomatologicheskoe materialovedenie: uchebnoe posobie. M.: Gjeotar Medicina, 2007; 192 s.

13. Jakushechkina EP. Povyshenie jeffektivnosti vosstanovlenija kontaktnogo punkta zhevatel'noj gruppy zubov [dissertacija]. Moskva, 2003.

14. Kalivradzhijan JeS, Bragin EA, Abakarov SI, Zholudev SE dr. Stomatologicheskoe materialovedenie. M.: Medicinskoe informacionnoe agentstvo, 2014; 320 s.

9. Ramos-Gomez F Yasmi CO, Man WN Crall JJ, Featherstone JDB Pediatric Dental Care: Prevention and management protocols based on caries risk assessment. J Calif Dent Assoc. 2010; 38 (10): 746-61.

10. Uma Maheswari S., Raja Jacob, Arvind Kumar I, and Gnana Seelan R. Caries management by risk assessment: A review on current strategies for caries prevention and management. $J$ Pharm Bioallied Sci. 2015 Aug; 7 (Suppl 2): 320-4.

11. Lorenzo Breschi, Annalisa Mazzoni, Fernando Nato, Marcela Carrilho, Erika Visintini, Leo Tjäderhane, Alessandra Ruggeri, Franklin R. Tay, Elettra De Stefano Dorigo, David H. Pashley. Chlorhexidine stabilizes the adhesive interface: A 2-year in vitro study. Dental Materials. 2010; 26 (4): 320-5.

12. Поюровская И. Я. Стоматологическое материаловедение: учебное пособие. М.: Гэотар Медицина, 2007; 192 с.

13. ЯкушечкинаЕ. П. Повышениеэффективностивосстановления контактного пункта жевательной группы зубов [диссертация]. Москва, 2003.

14. Каливраджиян Э. С., Брагин Е. А., Абакаров С. И., Жолудев С. Е. и др. Стоматологическое материаловедение. М.: Медицинское информационное агентство, 2014; 320 с. 